\title{
Concurrent treatment of metastatic breast and metastatic renal cell carcinoma: A case report
}

\author{
Sarah Jane Zardawi, Mathew Kattathra George
}

\begin{abstract}
Introduction: Breast and renal carcinomas are common malignancies, with an increasing number of well-tolerated targeted therapies. Case Report: We describe a case of concurrent, synchronous, metastatic breast and renal carcinomas where diagnosis was achieved after biopsy of two incongruous metastatic sites. The patient has been successfully treated with targeted therapies, exemestane and sunitinib, and later anastrozole and pazopanib, with radiological improvement and resolution of symptoms. Conclusion: Literature review of cases of antecedent, synchronous and metachronous breast and renal cancers (multiple malignancies), did not reveal increased risk of developing renal cancer after breast cancer, or of breast cancer after renal cancer. Cases of multiple breast and renal cancers appear to occur at any time with out clear reasons for their occurrence. This case demonstrates the importance of appropriate investigation and accurate diagnosis of synchronous malignancies in patients who may be candidates for treatment targeted therapies. As clinical experience of concurrent use of targeted therapies grows, including trials for potential additive benefits of using targeted
\end{abstract}

Sarah Jane Zardawi ${ }^{1}$, Mathew Kattathra George ${ }^{1}$

Affiliations: ${ }^{1}$ MBBS B Med Sci, Advanced Trainee, Calvary Mater Newcastle, Calvary Mater Hospital, Waratah, 2298, NSW, Australia; 'DM FRACP MSc, Adjunct Associate Professor, Staff Specialist in Medical Oncology and General Medicine, North West Cancer Center, Tamworth Rural Referral Hospital, NSW, Australia.

Corresponding Author: Sarah Jane Zardawi, Calvary Mater Newcastle, Waratah, NSW, Australia, 2298; Email: Sarah. Zardawi@calvarymater.org.au

Received: 01 October 2017

Accepted: 07 May 2018

Published: 03 August 2018 agents in combination, we will be able to offer improved treatment options for patients with both single and multiple malignancies.

Keywords: Multiple malignancies, Targeted therapies

\section{How to cite this article}

Zardawi SJ, George MK. Concurrent treatment of metastatic breast and metastatic renal cell carcinoma: A case report. J Case Rep Images Oncology 2018;4:100054Z10SZ2018.

Article ID: 100054Z10SZ2018

$$
* * * * * * * * *
$$

doi: 10.5348/100054Z10SZ2018CR

\section{INTRODUCTION}

Metastatic breast and renal carcinomas have an increasing number of well-tolerated, targeted therapies. This has made it possible to effectively treat patients whom otherwise might not have been considered for anticancer treatment, including patients with more than one advanced malignancy. This case report explores a patient with concurrent metastatic breast and renal carcinomas who has been treated successfully with two targeted therapies with radiological improvement and resolution of symptoms.

\section{CASE REPORT}

A 69-year-old female was incidentally noted to have a suspicious femoral lesion during elective right total knee replacement. This was on a background of a right breast carcinoma treated with mastectomy 35 years prior; a left breast carcinoma treated with partial mastectomy, adjuvant radiation and adjuvant tamoxifen 


\section{EDORIUM Journals}

14 years prior; and a right clear cell renal carcinoma treated with nephrectomy nine years prior. The femoral lesion was biopsied, revealing metastatic oestrogenand progesterone-receptor positive adenocarcinoma consistent with her prior hormone receptor positive left breast carcinoma (Figure $1 \mathrm{~A}-\mathrm{C}$ ). Staging computed tomography (CT) and FDG positron emission tomography (PET) identified multiple PET-avid lesions consistent with metastases in the pelvis, acetabulum, right femur, sternum, thoracic fifth and eighth vertebrae, and lumbar fifth vertebrae (Figure 2A). There was also a large, non PET-avid, pathological retro caval node, which was not in keeping with a diagnosis of metastatic breast carcinoma (Figure 2B). Biopsy of this node showed metastatic clear cell renal carcinoma consistent with her prior renal carcinoma (Figure $1 \mathrm{D}-\mathrm{F}$ ).

The patient received palliative radiotherapy to the sternum, thoracic spine, lumbar spine, left ilium and retro caval lymph nodes. She was initially commenced on exemestane and sunitinib and subsequently changed to anastrozole and pazopanib due to gastrointestinal adverse effects.

Restaging CT scan, bone scan, and PET scan have shown radiological response with reduction in size and PET avidity of her metastases. This response was durable for 24 months and associated with good symptom control and functional status. At time of commencement of therapy there was no subsidized access to cyclindependent kinase $4 / 6$ inhibitors.

\section{DISCUSSION}

Multiple malignancies are cases of multiple, pathologically distinct malignancies occurring in the one individual. The malignancies are described according to the time of diagnosis relative to the malignancy of interest. Antecedent malignancies occur at least 6 months prior to; synchronous malignancies are detected within six months; and metachronous malignancies are detected greater than six months after the malignancy of interest [1-4]. Antecedent, synchronous and metachronous malignancies are collectively referred to as multiple malignancies. Our case documents synchronous metastatic breast and renal carcinomas. The following discussion is based on a literature review using the PubMed database with the search terms breast carcinoma, breast cancer, renal carcinoma, renal cancer multiple malignancy, antecedent malignancy, synchronous malignancy and metachronous malignancy, as well as review of the references cited in articles retrieved through this search. Both full text articles and abstracts were included.

There are many instances of multiple malignancies involving breast and renal cancer, with previously reported case series listed in Table 1 [2-10]. However, despite these reported occurrences these series do not show an increased risk of developing renal cancer after

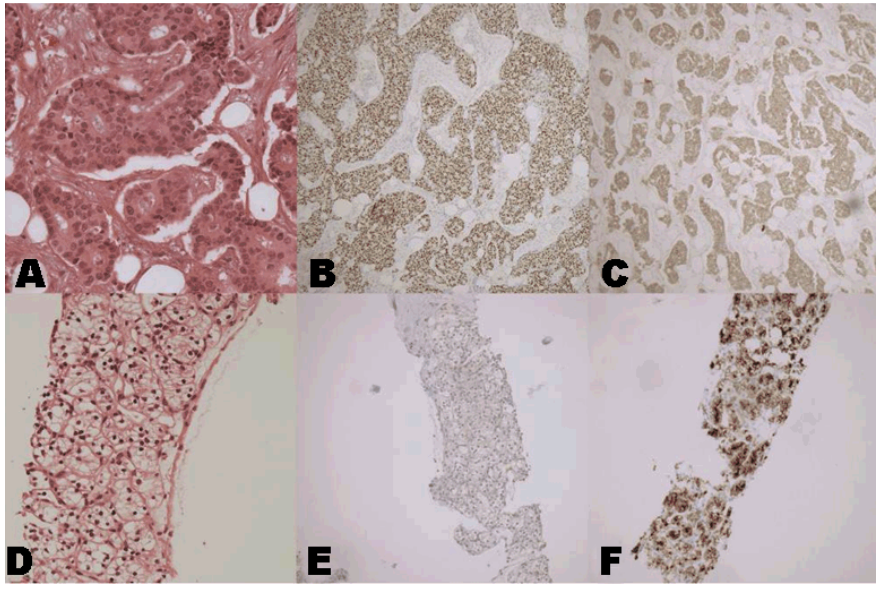

Figure 1(A-F): Histopathology of femoral lesion (A-C). (A) Haemotoxylin and eosin stain showing breast carcinoma metastasis, (B) positive ER stain, (C) positive Her-2 stain. Histopathology of retroperitoneal lesion (D-F). (D) Haemotoxylin and eosin stain showing renal cell carcinoma metastasis, (E) negative ER stain, (F) positive CD1o stain.

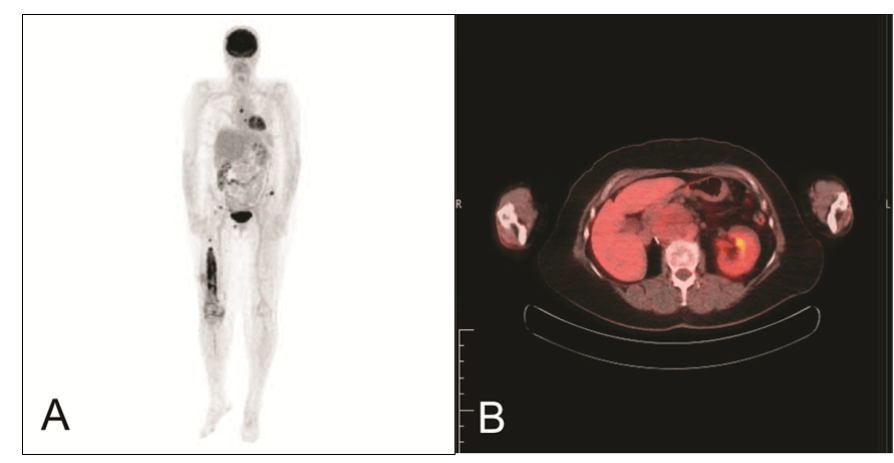

Figure 2(A-B): FDG PET images. (A) PET-CT image showing increased uptake at right femur. (B) PET-CT image showing low glucose avidity in enlarged retroperitoneal nodes.

breast cancer (standard incident ratio (SIR) 0.97-2.40 $[2,5])$ or of developing breast cancer after renal cancer (SIR 0.47-2.53 [2-4, 6-9]) compared to the background population risk of developing either malignancy.

The time interval between malignancies in our patient was 26 years between right breast and renal cancer, and 5 years between the left recurring breast and renal cancer. This is similar to the median published time to the development of breast cancer after renal cancer of 5.5-24.2 years $[4,7]$. Whilst this is the reverse order of malignancies to our case it highlights that metachronous malignancies can develop at any time.

Published case reports of patients with synchronous breast and renal carcinomas and are described in Table 2 [11-30]. Review of these cases show that it was more common to present with breast cancer (either early or advanced stage) and be diagnosed with a synchronous renal cancer [11-19]. When reported, the renal cell cancer was often a low grade and low stage cancer [11-17], or an incidental autopsy finding [18-19]. Interestingly, there were several cases of breast cancer metastasizing to a 


\section{EDORIUM Journals}

J Case Rep Images Oncology 2018;4:100054Z10SZ2018.

www.edoriumjournals.com/case-reports/jcro

Table 1: Published case series of multiple breast and renal cancers

\section{Metachronous renal cancer after breast cancer}

Hayat 2007 [2] 370,513 patients breast cancers; 136 cases metachronous renal cancer (antecedent SIR 0.97 and synchronous cancers renal cancers not reported).

Ricceri 2015 [5] 10,045 women breast cancer; 16 cases metachronous renal cancer (antecedent and SIR 2.40, (1.57-3.52) synchronous cancers excluded).

\section{Metachronous breast after renal cancer}

Kantor 1986 [9] 4,176 patients renal cancer; 18 cases metachronous breast cancer.

Not reported

Rabbani 2000763 patients renal cancer; 25 case antecedent breast cancer, 3 cases synchronous SIR 2.53 (o.69-6.5) [8] breast cancer, 4 cases metachronous breast cancer.

Czene 2002 [6] 23,137 patients renal cancer; 123 cases metachronous breast cancer (antecedent and SIR 1.25* (1.04-1.48) synchronous breast cancers not reported).

Sato 2004 [7] 319 patients renal cancer; 1 case antecedent breast cancer, 1 case metachronous Not reported breast cancer.

Bleisland $2006 \quad$ 14,250 patients renal cancer; 12 cases antecedent breast cancer, 6 cases synchronous SIR 1.00 (o.43-1.98) [3] breast cancer, 8 cases metachronous breast cancer.

Hayat 2007 [2] 49,632 patients renal cancer; 353 cases metachronous breast cancer (antecedent SIR 0.96 and synchronous breast cancers not reported).

Murray 2015 [4] 3,066 patients renal cancer; 12 cases metachronous breast cancer (antecedent SIR $0.47^{*}$ (0.24-0.83) cancers excluded, synchronous breast cancers not reported).

\section{Unspecified}

Jiao 2013 [10] 6,545 patients any malignancy; 5 cases synchronous breast cancer, 8 cases Not reported metachronous breast cancer, 1 case metachronous renal cancer.

Abbreviations: SIR - standard incident ratio, CI - confidence intervals (when reported), * - p<0.05

Table 2: Case reports considering multiple breast and renal carcinomas

\begin{tabular}{|c|c|c|}
\hline Case report & Presentation and treatment & Outcome \\
\hline Sella $1987[18]$ & $\begin{array}{l}62 \text { year-old female presented with metastatic breast carcinoma (T2N2M1, IDC). RCC } \\
\text { diagnosed at autopsy. Breast carcinoma metastasis to RCC. Further treatment not } \\
\text { described. }\end{array}$ & Not reported \\
\hline Piccinini 1996 [27] & $\begin{array}{l}2 \text { patients with synchronous diagnoses breast carcinoma and RCC. Further treatment } \\
\text { not described. }\end{array}$ & Not reported \\
\hline Val-Bernal $2001[19]$ & $\begin{array}{l}75 \text { year-old female presented with metastatic breast carcinoma (T2NoM1, IDC, ER/ } \\
\text { PR negative, Her2 positive). RCC diagnosed at autopsy. Breast carcinoma metastasis } \\
\text { to RCC. Further treatment not described. }\end{array}$ & Not reported \\
\hline Van Wynsberge 2004 [15] & $\begin{array}{l}64 \text { year-old female presented with recurrent metastatic breast carcinoma (ER } \\
\text { positive). Synchronous RCC. Breast carcinoma metastasis to RCC. Further treatment } \\
\text { not described. }\end{array}$ & Not reported \\
\hline Sachdev 2005 [29] & $\begin{array}{l}56 \text { year-old patient synchronous diagnoses breast carcinoma (ER/PR positive) and } \\
\text { clear cell RCC (T1aNXMX). Further treatment not described. }\end{array}$ & Not reported \\
\hline Moller 2006 [29] & $\begin{array}{l}62 \text { year-old female presented with RCC (T1aNoMo, grade I, clear cell) treated with } \\
\text { nephrectomy. Synchronous metastatic breast carcinoma (T4N3M1, IDC, ER/PR } \\
\text { positive, Her2 negative), treatment of which not described. }\end{array}$ & $\begin{array}{l}\text { Survival } \\
\text { months }\end{array}$ \\
\hline Perrin $2011[14]$ & $\begin{array}{l}\text { Patient presented with metastatic breast carcinoma (T2NXM1, IDC, ER/PR/Her2 } \\
\text { negative), treatment not described. Synchronous diagnosis RCC (clear cell) treated } \\
\text { with nephrectomy. }\end{array}$ & Not reported \\
\hline Kurlekar 2014 [13] & $\begin{array}{l}57 \text { year-old female presented with breast carcinoma (T2NoMo, ILC, ER/PR positive) } \\
\text { treated with modified mastectomy and adjuvant chemotherapy. Synchronous } \\
\text { diagnosis RCC (T1bNoMo, grade III, clear cell) treated with nephrectomy. }\end{array}$ & PFS $>18$ months \\
\hline Ureyen 2015 [12] & $\begin{array}{l}77 \text { year-old female presented with breast carcinoma (T2N1Mo, IDC, ER/PR positive, } \\
\text { Her2 negative) treated with modified mastectomy and axillary clearance, adjuvant } \\
\text { radiotherapy and aromatase inhibitor. Synchronous RCC (T1aNoMo, grade III, clear } \\
\text { cell) treated with nephrectomy. }\end{array}$ & PFS $>16$ months \\
\hline
\end{tabular}




\section{EDORIUM Journals}

J Case Rep Images Oncology 2018;4:100054Z10SZ2018.

www.edoriumjournals.com/case-reports/jcro

Zardawi et al. 4

Table 2: (Continued)

\begin{tabular}{|c|c|c|c|}
\hline Huo 2015 [16] & & $\begin{array}{l}43 \text { year-old female presented with metastatic breast carcinoma (IDC, ER/PR } \\
\text { positive, Her2 negative) treated with palliative chemotherapy, GNRH agonist and } \\
\text { aromatase inhibitor. Synchronous RCC (T1aNoMo, grade II, clear cell) treated with } \\
\text { partial nephrectomy. Breast carcinoma metastasis to RCC. }\end{array}$ & PFS \\
\hline Chen 2015 [17] & & $\begin{array}{l}74 \text { year-old female presented with breast carcinoma (pT2pNoMo, IDC, grade I, ER/ } \\
\text { PR/Her2 negative). Synchronous metastatic RCC to breast (pT3pNocM1, grade II, } \\
\text { clear cell). Further treatment not described. }\end{array}$ & Not reported \\
\hline Mosholt 2015 [30] & & $\begin{array}{l}71 \text { year-old-female presented with RCC (clear cell). Synchronous metastatic breast } \\
\text { carcinoma. Further treatment not described. }\end{array}$ & Not reported \\
\hline Arjunan 2016 [11] & & $\begin{array}{l}45 \text { year-old female presented with breast carcinoma (T2N2Mx, grade III, IDC, } \\
\text { ER positive) treated with modified mastectomy and adjuvant chemotherapy. } \\
\text { Synchronous diagnosis RCC (pT1NoMo, grade III, papillary carcinoma) treated with } \\
\text { nephrectomy. }\end{array}$ & Not reported \\
\hline $\begin{array}{l}\text { Urdiales-Viedma } \\
\text { [20] }\end{array}$ & 2016 & $\begin{array}{l}71 \text { year-old female presented with RCC (clear cell). Synchronous metastatic breast } \\
\text { carcinoma. Breast carcinoma metastasis to RCC. Further treatment not described. }\end{array}$ & Not reported \\
\hline Noguchi 2017 [21] & & $\begin{array}{l}67 \text { year-old female synchronous diagnosis metastatic breast carcinoma (T2NoM1, } \\
\text { ILC) treated with hormonal therapy and RCC (T1aNoMo, clear cell) treated with } \\
\text { nephrectomy. Breast carcinoma metastasis to RCC }\end{array}$ & PFS $>5$ months \\
\hline
\end{tabular}

Abbreviations: IDC - Invasive ductal carcinoma; ILC - Invasive lobular carcinoma; ER - Oestrogen receptor; PR - Progesterone receptor; Her-2 - human epidermal growth factor receptor 2; RCC - renal cell carcinoma; PFS - progression or disease free survival.

renal cancer, known as tumour-to-tumour metastases [15-21], but no cases of renal cancer metastasizing to a breast cancer. Further, there are no cases like ours that report synchronous metastatic breast and metastatic renal cancers.

Age is a known risk factor for multiple malignancies with one case series of renal cancers documenting that patients with synchronous or metachronous malignancies of anytypewerefiveyears older than thosewithout a second malignancy $(\mathrm{P}=0.0072)$ [8]. Otherwise, the development of second malignancies is thought to be dependent upon lifestyle factors, previous cancer treatments and genetic susceptibilities. For breast and renal cancers, there are common life style risk factors of cigarette smoking and obesity [5, 22-23] but the treatments used for breast and renal cancer are not associated with an increased risk of the other malignancy [24-26], nor are there common inherited genetic conditions. Despite an absence of clear causative reasons for multiple malignancies, as treatment of cancer and other diseases improves it is likely that the incidence of patients with multiple malignancies will increase.

Our patient was commenced on the targetted therapies, exemestane and sunitinib, and subsequently anastrozole and pazopanib for treatment of her metastatic breast and renal carcinomas. Exemestane and anastrozole are aromatise inhibitors that prevent the conversion of circulating oestrogen pre-cursors to oestrogen to reduce exposure of growth promoting oestrogen to breast cancer cells [31]. Sunitinib and pazopanib are tyrosine kinase inhibitors that prevent the activation of vascular endothelial growth factor receptors, platelet derived growth factors and stem cell factor receptor to affect the survival, proliferation, vascularization and metastasis of renal cancer cells [32]. Whilst these therapies have established efficacy for treatment of their respective malignancies, current phase II clinical trials are testing combined use of targeted therapies for potential increased efficacy in post menopausal breast cancer. These trials include the use of pazopanib with an aromatase inhibitor for the neoadjuvant treatment of stage II-III breast cancer [33], and with an aromatase inhibitor following development of resistance in metastatic breast cancer [34]. Such studies may explain why our patient has had such a significant response to treatment (noting that she also had palliative radiotherapy to most sites of disease), as well as offer improved treatment options for patients with both single and multiple malignancies.

Previously multiple malignancies have previously been associated with poorer outcomes. Two case series of renal cancers found that patients with antecedent or synchronous cancers had 5-year survival rates of approximately $30 \%$ compared with 50\% for patients without a second malignancy [3]. Sato et al also demonstrated that an antecedent or synchronous tumour, like a high pathological stage, was a strong independent poor prognostic factor for overall survival in patients with renal cell cancer [7]. Further, the median survival time was vastly worse for synchronous cancers than for metachronous cancer (3.8 years versus 17.3 years, $\mathrm{p}<0.05$ ) [7], potentially due to the challenges of treating two malignancies at the same time. Fortunately, our patient has had durable response to treatment for 24 months, which may suggest improved outcomes for these patients with targeted therapies. 


\section{EDORIUM Journals}

\section{CONCLUSION}

This case demonstrates the importance of appropriate investigation and accurate diagnosis of synchronous malignancies in patients who may be candidates for treatment with multiple targeted therapies, which is a situation that is anticipated to become more common in the future due to improving health outcomes and cancer therapies. As clinical experience of concurrent use of targeted therapies grows, including trials for potential additive benefits of using targeted agents in combination, we will be able to offer improved treatment options for patients with both single and multiple malignancies.

\section{REFERENCES}

1. Moertel CG. Multiple primary malignant neoplasms: Historical perspectives. Cancer 1977 Oct;40(4 Suppl):1786-92.

2. Hayat MJ, Howlader N, Reichman ME, Edwards BK. Cancer statistics, trends, and multiple primary cancer analyses from the surveillance, epidemiology, and end results (SEER) program. Oncologist 2007 Jan;12(1):20-37.

3. Beisland C, Talleraas O, Bakke A, Norstein J. Multiple primary malignancies in patients with renal cell carcinoma: A national population-based cohort study. BJU Int 2006 Apr;97(4):698-702.

4. Murray KS, Zabor EC, Spaliviero M, et al. Second primary malignancies in renal cortical neoplasms: An updated evaluation from a single institution. World $\mathrm{J}$ Urol 2016 Dec;34(12):1667-72.

5. Ricceri F, Fasanelli F, Giraudo MT, et al. Risk of second primary malignancies in women with breast cancer: Results from the European prospective investigation into cancer and nutrition (EPIC). Int $\mathrm{J}$ Cancer 2015 Aug 15;137(4):940-8.

6. Czene K, Hemminki K. Kidney cancer in the Swedish family cancer database: Familial risks and second primary malignancies. Kidney Int 2002 May;61(5):1806-13.

7. Sato S, Shinohara N, Suzuki S, Harabayashi T, Koyanagi T. Multiple primary malignancies in Japanese patients with renal cell carcinoma. Int $\mathrm{J}$ Urol 2004 May;11(5):269-75.

8. Rabbani F, Reuter VE, Katz J, Russo P. Second primary malignancies associated with renal cell carcinoma: Influence of histologic type. Urology 2000 Sep 1;56(3):399-403.

9. Kantor AF, McLaughlin JK, Curtis RE, Flannery JT, Fraumeni JF Jr. Risk of second malignancy after cancers of the renal parenchyma, renal pelvis, and ureter. Cancer 1986 Sep 1;58(5):1158-61.

10. Jiao F, Yao LJ, Zhou J, Hu H, Wang LW. Clinical features of multiple primary malignancies: A retrospective analysis of 72 Chinese patients. Asian Pac J Cancer Prev 2014;15(1):331-4

11. Arjunan R, Kumar D, Kumar KV, Premlatha CS. Breast cancer with synchronous renal cell carcinoma: A rare presentation. J Clin Diagn Res 2016 Oct;10(10):XDo3-XDo5
12. Üreyen $\mathrm{O}$, Dadali $\mathrm{E}$, Akdeniz $\mathrm{F}$, et al. Co-existent breast and renal cancer. Ulus Cerrahi Derg 2015 Jul 10;31(4):238-40.

13. Kurlekar UA, Rayate AS. Synchronous primary malignancies in breast and kidney: A rare case report. Indian J Surg 2015 Apr;77(Suppl 1):6-9.

14. Perrin C, Talarmin M, Fontaine A, et al. Breast carcinoma metastasis into a renal cell carcinoma. [Article in French]. Ann Pathol 2011 Oct;31(5):399401.

15. Van Wynsberge LK, Vierling P, Lampel A. Breast cancer metastatic to a renal cell carcinoma. [Article in German]. Aktuelle Urol 2004 Nov;35(6):505-7.

16. Huo Z, Gao Y, Yu Z, Zuo W, Zhang Y. Metastasis of breast cancer to renal cancer: Report of a rare case. Int J Clin Exp Pathol 2015 Nov 1;8(11):15417-21.

17. Chen TD, Lee LY. A case of renal cell carcinoma metastasizing to invasive ductal breast carcinoma. J Formos Med Assoc 2014 Feb;113(2):133-6.

18. Sella A, Ro JY. Renal cell cancer: Best recipient of tumor-to-tumor metastasis. Urology 1987 Jul;30(1):35-8.

19. Val-Bernal JF, Villoria F, Pérez-Expósito MA. Concurrent angiomyolipomas and renal cell carcinoma harboring metastatic foci of mammary carcinoma in the same kidney: An incidental autopsy finding in a patient with a follow-up of thirty years. Ann Diagn Pathol 2001 Oct;5(5):293-9.

20. Urdiales-Viedma M, Luque RJ, Valle F, MartosPadilla S. Clear cell renal cell carcinoma metastasized by a breast ductal carcinoma. [Article in Spanish]. Arch Esp Urol 2016 May;69(4):197-201.

21. Noguchi G, Saito Y, Mitome T, et al. Renal cell carcinoma with retroperitoneal metastases and renal invasion from breast cancer: A case report. [Article in Japanese]. Hinyokika Kiyo 2017 Apr;63(4):151-5.

22. World cancer research fund international. Kidney cancer statistics. [Available at: http://www.wcrf. org/int/cancer-facts-figures/data-specific-cancers/ kidney-cancer-statistics]

23. World cancer research fund international. Breast cancer statistics. [Available at: http://www.wcrf. org/int/cancer-facts-figures/data-specific-cancers/ breast-cancer-statistics]

24. Schaapveld M, Visser O, Louwman MJ, et al. Risk of new primary nonbreast cancers after breast cancer treatment: A Dutch population-based study. J Clin Oncol 2008 Mar 10;26(8):1239-46.

25. Matesich SM, Shapiro CL. Second cancers after breast cancer treatment. Semin Oncol 2003 Dec;30(6):7408.

26. Argani P, Laé M, Ballard ET, Amin M, et al. Translocation carcinomas of the kidney after chemotherapy in childhood. J Clin Oncol 2006 Apr 1;24(10):1529-34.

27. Piccinini L, Luppi G, Zoboli A, Torricelli P. Occasional diagnosis of synchronous renal cell carcinoma during staging of other primary tumors. Tumori $1996 \mathrm{Sep}-$ Oct;82(5):488-90.

28. Sachdev R, Jain S, Nigam S, Agarwal P. Synchronous primary tumors of kidney and breast. The Internet Journal of Urology 2005;4:1.

29. Möller MG, Gribbin T, Ebrom S, Padula G, Fitzgerald TL. Breast cancer metastatic to renal cell carcinoma. Surgery 2006 Apr;139(4):577-9. 


\section{EDORiUM Journals}

30. Mosholt KS, Pilt AP, Wittendorff HE. Breast carcinoma metastasis to the gastrointestinal tract and tumour-to-tumour metastasis to renal cell carcinoma. [Article in Danish]. Ugeskr Laeger 2015 Apr 6;177(15):V10140574.

31. Ackland SP. Drug treatment of breast cancer. Aust Prescr 1998 Jan;21(1):15-9.

32. Carrington C. Oral targeted therapy for cancer. Aust Prescr 2015 Oct;38(5):171-6.

33. ClinicalTrials.gov. Neo-adjuvant therapy with anastrozole plus pazopanib in stage II and III ER+ breast cancer: NCTo1394211. [Available at: https:// clinicaltrials.gov/ct2/show/NCTo1394211]

34. ClinicalTrials.gov. Reversing hormone resistance in advanced breast cancer with pazopanib: NCTo1466972. [Available at: https://clinicaltrials. gov/ct2/show/NCTo1466972]

$$
* * * * * * * * *
$$

\section{Acknowledgements}

Brianna Wright, Christopher Renaud, Susan Pendlebury.

\section{Author Contributions}

Sarah Jane Zardawi - Acquisition of data, Analysis and interpretation of data, Drafting the article, Revising it critically for important intellectual content, Final approval of the version to be published
Mathew Kattathra George - Substantial contributions to conception and design, Revising it critically for important intellectual content, Final approval of the version to be published

\section{Guarantor of Submission}

The corresponding author is the guarantor of submission.

\section{Source of Support}

None.

\section{Consent Statement}

Written informed consent was obtained from the patient for publication of this case report.

\section{Conflict of Interest}

Authors declare no conflict of interest.

\section{Copyright}

(C) 2018 Sarah Jane Zardawi et al. This article is distributed under the terms of Creative Commons Attribution License which permits unrestricted use, distribution and reproduction in any medium provided the original author(s) and original publisher are properly credited. Please see the copyright policy on the journal website for more information.
Access full text article on other devices

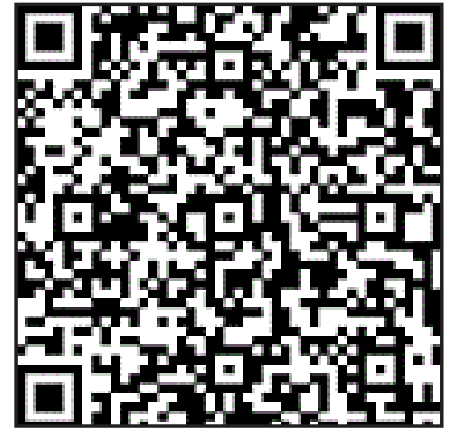

Access PDF of article on other devices

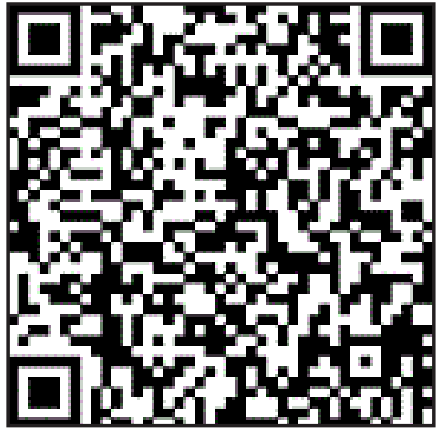

